Pesq. Vet. Bras. 37(12):1411-1415, dezembro 2017 DOI: $10.1590 / \mathrm{S} 0100-736 \mathrm{X} 2017001200009$

\title{
Acaricidal activity of ethanolic extracts of Stryphnodendron adstringens and Lafoensia pacari and oil resins from Copaifera sp. and Pterodon emarginatus against Sarcoptes scabiei var. suis ${ }^{1}$
}

\author{
Adriana Marques Faria ${ }^{2 *}$, Adriana da Silva Santos ${ }^{3}$, Lorena Lopes Ferreira ${ }^{2}$, Thiago \\ Souza Azeredo Bastos², Carla Cristina Braz Louly ${ }^{3}$, Moema Pacheco Chediak Matos², \\ Edemilson Cardoso da Conceição ${ }^{4}$ and Veridiana Maria Brianezi Diganai de Moura ${ }^{2}$
}

\begin{abstract}
Faria A.M., Santos A.S., Ferreira L.L., Bastos T.S.A., Louly C.C.B., Matos M.P.C., Conceição E.C. \& Moura V.M.B.D. 2017. Acaricidal activity of ethanolic extracts of Stryphnodendron adstringens and Lafoensia pacari and oil resins from Copaifera sp. and Pterodon emarginatus against Sarcoptes scabiei var. suis. Pesquisa Veterinária Brasileira 37(12):14111415. Escola de Veterinária e Zootecnia, Universidade Federal de Goiás, Campus II, Samambaia, Cx. Postal 131, Goiânia, G0 74001-970, Brazil. E-mail: adrianafaria.vet@gmail.com

In vitro bioassay using Sarcoptes scabiei as a test microorganism is a viable method of study for diverse drugs with acaricidal properties. A great amount of assays proves the diverse and efficient biological activity of extracts and compounds from Brazilian savanna plants. This study had as main object, test and compare the acaricidal activity of four Brazilian Cerrado bioproducts: Stryphnodendron adstringens Mart., Copaifera sp., Lafoensia pacari A. St Hil. and Pterodon emarginatus Vogel, 1837. To perform this test S. scabiei mites were collected from crusts removed on ears of highly infected sows. The mites were selected and separated in Petri dishes with three different concentrations $(25,50$ and $75 \%)$ of each bioproduct, to evaluate their potential acaricidal activity. The mortality of the mites was counted in each Petri dish every hour, during five hours. The statistical analyses demonstrated differences between the bioproducts tested. The oleoresin of Copaifera sp. and $P$. emarginatus presented the best results with $100 \%$ of mites mortality after treatment. The ethanolic extracts of S. adstringens and L. pacari demonstrated lower acaricidal activity when compared to the oleoresins, with little or no difference among the control groups tested. This bioassay demonstrated to be efficient, reliable, low cost and easy accomplishment. Oil resins from Copaifera sp. and P. emarginatus have in vitro acaricidal activity against adult females of $S$. scabiei var. suis.
\end{abstract}

INDEX TERMS: Acaricidal activity, ethanolic extracts, Stryphnodendron adstringens, Lafoensia pacari, oil resins, Copaifera sp., Pterodon emarginatus, Sarcoptes scabiei var. suis, bioassay, bioproducts, Brazilian Cerrado.

RESUMO.- [Atividade acaricida dos extratos etanólicos de Stryphnodendron adstringens Mart. e Lafoensia pacari A. St Hil., bem como das óleo-resinas de Copaife-

\footnotetext{
${ }^{1}$ Received on October 17, 2016.

Accepted for publication on April 25, 2017.

${ }^{2}$ Escola de Veterinária e Zootecnia, Universidade Federal de Goiás (UFG), Campus II, Samambaia, Cx. Postal 131, Goiânia, GO 74001-970, Brazil. *Corresponding author: adrianafaria.vet@gmail.com

${ }^{3}$ Instituto Federal Goiano, Campus Urutaí, Rodovia Geraldo Silva Nascimento Km 2,5, Urutaí, GO 75790-000, Brazil.

${ }^{4}$ Faculdade de Farmácia, UFG, Av. Universitária com 1a Avenida s/n, Campus I, Setor Universitário, Goiânia, GO 74605-220, Brazil.
}

ra sp. e Pterodon emarginatus Vogel, 1837 contra Sarcoptes scabiei var. suis.] O uso de Sarcoptes scabiei como microrganismo teste para bioensaio in vitro é um método de estudo viável para diversas drogas acaricidas. Muitos ensaios comprovam a diversidade e eficiência de atividade biocida de extratos e componentes presentes em plantas do cerrado brasileiro. Este trabalho objetivou testar e comparar a atividade acaricida de quatro bioprodutos do cerrado brasileiro: Stryphnodendron adstringens Mart., Lafoensia pacari A. St Hil., Copaifera sp. e Pterodon emarginatus Vogel, 1837. Para este estudo, ácaros $S$. scabiei foram colhidos em crostas removidas de orelhas de fêmeas suínas altamente 
infestadas. Os ácaros foram selecionados, separados e colocados em placas de Petri com três diferentes concentrações $(25,50$ e $75 \%)$ de bioprodutos, para avaliar o potencial de atividade acaricida de cada um. Foi realizada a contagem da mortalidade dos ácaros em cada placa de Petri a cada hora, durante cinco horas. As análises estatísticas demonstraram diferenças entre os bioprodutos testados. As óleo-resinas de Copaifera sp. e P. emarginatus apresentaram os melhores resultados, com $100 \%$ de mortalidade dos ácaros após tratamento. Os extratos etanólicos de $S$. adstringens Mart. e L. pacari demonstraram menor atividade acaricida quando comparados as óleo-resinas, com pequena ou nenhuma diferença entre os resultados dos grupos controle. Este ensaio demonstrou ser uma ferramenta eficiente, confiável, de baixo custo e de fácil realização. As óleo-resinas Copaifera sp. e P. emarginatus possuem atividade acaricida in vitro sobre fêmeas adultas de S. scabiei var. suis.

TERMOS DE INDEXAÇÃO: Acaricida, extratos etanólicos, Stryphnodendron adstringens, Lafoensia pacari, óleo-resinas, Copaifera sp., Pterodon emarginatus, Sarcoptes scabiei var. suis, bioensaio, bioprodutos, Cerrado Brasileiro.

\section{INTRODUCTION}

Sarcoptes scabiei, an ectoparasitic mite, causes a skin disease referred to as scabies in humans and as sarcoptic mange in other animal species. S. scabiei affects a wide range of animals worldwide, with particularly vulnerable animals including pigs, dogs, camelid species, wombats and koalas (Pence \& Ueckermann 2002). In pigs it is considered the most important ectoparasite due to severity, persistent itch, but may also lead to secondary infections and reproductive distress (Sobestiansky et al. 2012).

Chemical acaricides is the common method of mite control, and these compounds have been demonstrated drug resistance and environmental toxicity. Because of that, botanical acaricides became an interesting alternative due their safety and efficacy (Deng et al. 2012). The biocidal activity of many plants have been studied along of the last decade (Walton et al. 2004, Abdel-Ghaffar et al. 2008, Du et al. 2008, Deng et al. 2012, Nong et al. 2012). In Brazil, the flora is very distinct and there still a lot to discover about new compounds that can be used to treat infectious diseases among other benefits (Jesus et al. 2009). A great amount of assays proves the diverse and efficient biological activity of extracts and compounds from savanna plants (Reichling et al. 2009).

Pterodon emarginatus Vogel, 1837 is a traditional plant species with popular use in Brazil, anti-parasitic properties are well know among other effects such as anti-inflammatory and microbicide activity (Hansen et al. 2010, Oliveira et al. 2017). The versatility in bioactivity seen in Copaife$r a$ genus awakes vast interest in many studies, since anti-protozoan and repellent effects among different species of parasites showed promising results (Izumi et al. 2012, Souza et al. 2017). Different species of Stryphnodendron and plant parts are used to inhibit predatory bugs in crops as alternative to pharmaceutical products (Webber 2009), and presents antiseptic and antiprotozoal activities (Ribeiro et al. 2015). Lafoensia pacari has ellagitannin, with efficient anti-inflammatory, antimicrobial and angiogenic properties (Carneiro et al. 2016).

There is no information about the effects of ethanolic extracts or any oil-resins from Brazil against $S$. scabiei. Therefore, in order to evaluate the possible acaricidal activity, we used ethanolic extracts from S. adstringens Mart. ("barbatimão") and L. pacari A. St Hil. ("pacari") and oil-resins from Copaifera sp. ("copaíba") and P. emarginatus ("sucupira branca") against $S$. scabiei var. suis.

\section{MATERIALS AND METHODS}

Plant materials. The Pterodon emarginatus fruits were obtained from Urban Market in Goiânia, Goiás State, Brazil. Plant bark from Stryphnodendron adstringens was acquired from a commercial company (PALADAR, Goiânia, Goiás, Brazil). Fruit pell from Lafoensia pacari were collected in Niquelândia City, Goiás State, Brazil. Oil resin from Copaifera sp. was also acquired from a commercial company ready for use (NUTRAGYN Ltda, Goiânia, Goiás, Brazil).

Oil resin extraction and plant material preparation. Bark from L. pacari and S. adstringens were individually sanitized, dried and dehydrated. The extracts obtained were then percolated with hydroalcoolic solution at $80 \%$ and concentrated in an industrial rotaevaporator (Buchi ${ }^{\circledR}$ model R-220 SE). The material collected were kept away from light and under refrigeration. The extraction of P. emarginatus oil resin from fruits was made by a company (ECIRTEC, Bauru, São Paulo, Brazil).

Mites collection. Adult females of Sarcoptes scabiei var. suis were isolated from naturally infested sows. Scabs collected from infections of the ear were placed in Petri dishes and transported to the laboratory. Under a stereomicroscope (Leica Zoom 2000), $S$. scabiei adult females were easily distinguished from the other mites because of their size $(0.4 \mathrm{~mm})$ as observed by Evans (1992). This protocol was approved by the Ethics Committee on Animal Use and Experimentation of UFG (CEUA/UFG 002/2012).

In vitro acaricidal assay. Mite bioassays were conducted following a method previously described (Walton et al. 2000) with some minimum modifications. The ethanolic extracts from $S$. adstringens and L. pacari and the oil resins from Copaifera sp. and P. emarginatus were diluted in distillated water and $2 \%$ of Tween 20 . The solutions and emulsions were spread evenly across the surface of Petri dishes $(10 \mathrm{~cm}$ in diameter) using a sterile swab. Female adult mites were placed in the Petri dishes, with a total of 10 mites per plate. Distillated water and Tween 20 at $2 \%$ were used as control. All solutions and emulsions were diluted at three different concentrations $(25 \%, 50 \%$ and $75 \%)$ and were performed in triplicate.

The plates were placed in a climatic chamber $(\mathrm{RH}=80 \%$, $\mathrm{T}=25^{\circ} \mathrm{C}$ ) and were observed by stereomicroscope. The deaths were counted during the 1st hour and hourly the following five hours. Immobility of the larval mites, even when stimulated with a needle, the lack of a reaction, and persistent immobility were considered indicative of death, according to Walton et al. (2000).

Statistical analysis. Results were evaluated using One-way analysis of variance (ANOVA) test and non-parametric Kruskal-Wallis test were used to quantitative variables which did not shown normal distribution using R software (Lucent Technologies).

\section{RESULTS}

There were considerable differences in acaricidal activity between solutions and emulsions (Table 1). Emulsions showed better activity then solutions. Even that, the lowest 
concentration caused higher mortality rate. Mortalities of the Sarcoptes scabiei are shown in Figure 1. The oil resin from Copaifera sp. at $25 \%$ concentration showed $100 \%$ of mites mortality in the first three hours, and the concentrations of 50 and $75 \%$ reached a maximum mortality rate of 73,3 and $83 \%$ within two and four hours, respectively.

The oil resin from Pterodon emarginatus at $25 \%$ was able to kill $94 \%$ of mites within four hours, and the upper concentrations reached mortality rate of 66 and $80 \%$, respectively. Ethanolic extracts solutions of Stryphnodendron adstringens and Lafoensia pacari showed a lower acaricidal activity in comparison with the oil resins tested being

Table 1. Sarcoptes scabiei var. suis female mortality rate (in vitro) using solutions of Stryphnodendron adstringens

Mart. and Lafoensia pacari A. St Hil. and emulsions of Copaifera sp. and Pterodon emarginatus Vogel, 1837 at three different concentrations

\begin{tabular}{lc}
\hline Treatments & Mean mortality (\%) \\
\hline Distilled water & $9.6 \mathrm{~d}$ \\
ECS 25\% & $44.0 \mathrm{a}$ \\
ECS 50\% & $35.6 \mathrm{ab}$ \\
ECS 75\% & $40.0 \mathrm{a}$ \\
EPE 25\% & $42.0 \mathrm{a}$ \\
EPE 50\% & $35.6 \mathrm{ab}$ \\
EPE 75\% & $38.3 \mathrm{a}$ \\
SLP 25\% & $22.0 \mathrm{~cd}$ \\
SLP 50\% & $9.6 \mathrm{~d}$ \\
SLP 75\% & $23.3 \mathrm{bc}$ \\
SSA 25\% & $11.6 \mathrm{~cd}$ \\
SSA 50\% & $12.3 \mathrm{~cd}$ \\
SSA 75\% & $18.0 \mathrm{~cd}$ \\
Tween 20 at 2\% & $16.6 \mathrm{~cd}$
\end{tabular}

Different letters indicate significance according Kruskal-Wallis test $(\mathrm{P}<0.001) . \mathrm{SSA}=$ solution of Stryphnodendron adstringens, $\mathrm{SLP}=$ solution of Lafoensia pacari, $\mathrm{ECS}=$ emulsion of Copaifera sp., EPE $=$ emulsion of Pterodon emarginatus.

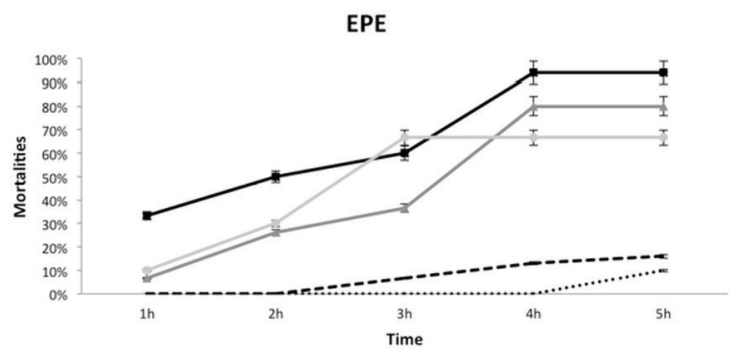

SLP

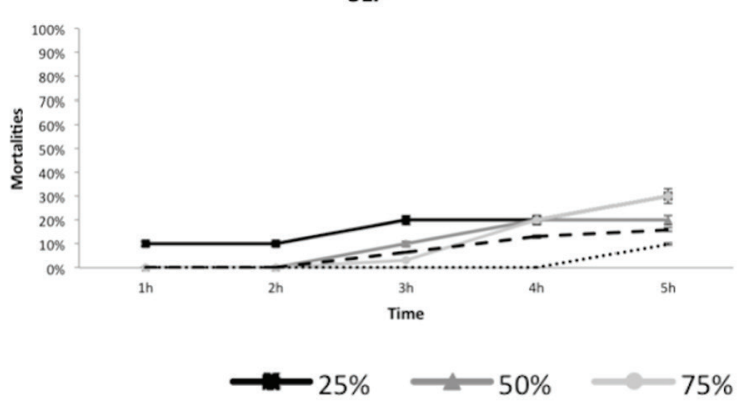

lower than $30 \%$ of mortality. Control and Tween $20 \mathrm{kept}$ a maximum mortality of $16 \%$ at the end of the five hours.

\section{DISCUSSION}

Here we presented the first acaricidal study with Stryphnodendron adstringens and Lafoensia pacari and oil resins from Copaifera sp. and Pterodon emarginatus against Sarcoptes scabiei var. suis. We founded that oil resins of Copaifera sp. and P. emarginatus at lowest concentration showed in vitro higher mortalities, while ethanolic extract of S. adstringens and L. pacari did not caused reasonable mortality rate.

In general, topical scabicidal act by neurotoxicity, but can act by asphyxiation (Archer et al. 2014) once mite respiration occurs through tegument once the absence of a tracheal system (Evans 1992). Little is known about the action mode of many plants materials, but the beneficial effects result from single or combinations of active compounds present in the plant (Ravindran et al. 2012).

Better acaricidal effect of oil resins probably happened due to its lipophilic compounds and possibly difficulty to obtain a homogeneous emulsion in water composition (Davanço et al. 2007). Tween 20 is a nonionic detergent that can modified surface properties of liquids (Sigma Aldrich 2017) and increase penetration of the emulsion created by increasing contact area, besides that when this substance is used a lower dose of the principal compound can be effective (Embrapa 2006). Even that, acaricidal activity of the oil resins can be attributed to the rich terpenoid composition that have been proved to have a satisfactory effect against S. scabiei and other mites (Poppenga 2007, Xu et al. 2010, Walton et al. 2010, Deng et al. 2012, Nong et al. 2012).

Copaifera sp. oils, as extensively discussed in literature, are mainly composed by sesquiterpenes (hydrocarbon and oxygenated compounds) and acidic diterpenes (Veiga
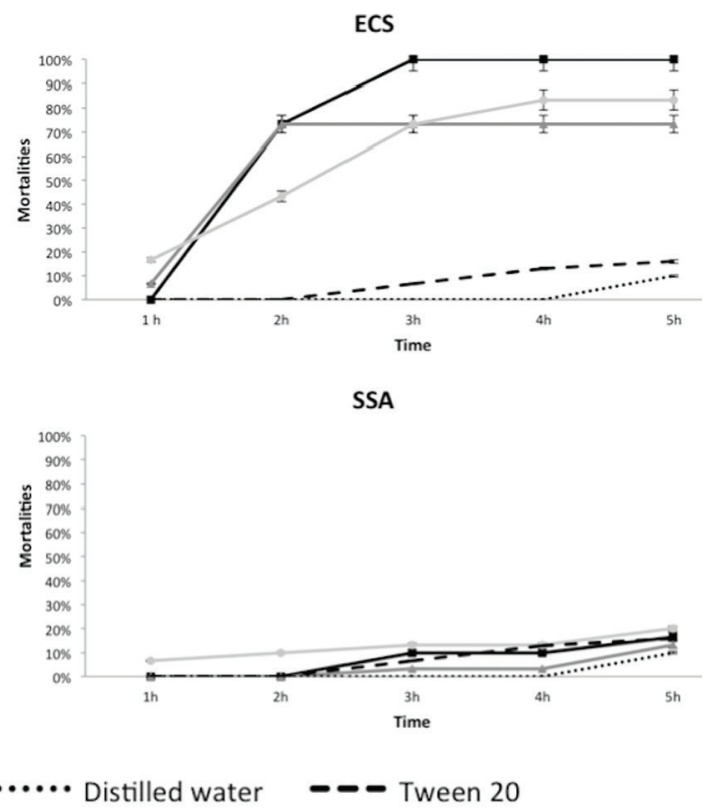

Fig.1. In vitro mortality rate of Sarcoptes scabiei var. suis females during five hours after Pterodon emarginatus emulsion (EPE), Copaifera sp. emulsion (ECS), Lafoensia pacari solution (SLP) and Stryphnodendron adstringens solution (SSA) application at three different concentrations $(25 \%, 50 \%$ and $75 \%)$. 
Junior \& Pinto 2002). It is used in popular medicine and industry, and its main activities are antitumor, anti-inflammatory, anti-allergic, bactericidal and insecticidal properties (Gomes et al. 2010). Historically, Copaifera trees has potentially been used in treatment of several diseases and Izumi et al. (2012) has shown its ability to inhibit different Trypanosoma cruzi life stages in vitro. P. emarginatus oil resin has high concentrations of $\gamma$-muuroleno, biciclogermacren and lupeol, among other terpenoides hydrocarbons. A few studies in Brazil has shown the anti-inflammatory, analgesic and bactericidal activities from $P$. emarginatus substances (Souza et al. 2007, Pereira et al. 2011, Moraes et al. 2012), and recently larvicidal activity against Culex quinquefasciatus (Oliveira et al. 2017).

Low mortality rate of $S$. adstringens and L. pacari extracts can be attributed to a different composition that is seasonal and geographic dependent (Santos et al. 2010). Both extracts have been related with insecticidal activities (Mazzonetto \& Vendramim 2003, Rogério et al. 2008), but mostly, they have been reported with high presence of anti-inflammatory and anti-oxidant compounds, where substances such as tannins (Porfírio et al. 2009, Silva Júnior et al. 2010, De Paula et al. 2010). Further studies must be done to verify the potential in vivo activity, once botanical fractions and bioproducts are preferred for their economic benefits, low environmental persistence, lack of resistance in arthropods and relative non-toxicity to animals (Du et al. 2008).

\section{CONCLUSIONS}

Oil resins from Copaifera sp. and Pterodon emarginatus have in vitro acaricidal activity against adult females of Sarcoptes scabiei var. suis.

It is necessary to investigate the real potential of those plants as acaricidal therapy and isolate the specific acaricidal substances as prospective for new efficient products.

Acknowlegments.- The authors thank Professor Luiz Augusto Batista Brito. They also thank Conselho Nacional de Desenvolvimento Científico e Tecnológico - CNPq for funding this research (Grant 564071/2010-2 - PRO-CENTRO-OESTE).

\section{REFERENCES}

Abdel-Ghaffar F., Al-Quraishy S., Sobhy H. \& Semmler M. 2008. Neem seed extract shampoo, Wash Away Louse ${ }^{\circledR}$, an effective plant agent against Sarcoptes scabiei mites infesting dogs in Egypt. Parasit. Res. 104:145148.

Archer M., Steinvoort C., Larson B. \& Oderda G. 2014. Pediculicides and Scabicides Drug Class Review. College of Pharmacy, University of Utah, Salt Lake City. 18p.

Carneiro C.C., Da Costa Santos S., De Souza Lino R., Bara M.T.F., Chaibub B.A., De Melo Reis P.R. \& Chen-Chen L. 2016. Chemopreventive effect and angiogenic activity of punicalagin isolated from leaves of Lafoensia pacari A. St Hil. Toxicol. Appl. Pharmacol. 310:1-8.

Davanço T., Palmu P.T. \& Grosso C. 2007. Filmes compostos de gelatina, triacetina, ácido esteárico ou capróico: efeito do pH e da adição de surfactantes sobre a funcionalidade dos filmes. Ciênc. Tecnol. Aliment. 27: 408-416.

De Paula R.C., Sanchez E.F., Costa T.R., Martins C.H.G., Pereira P.S., Lourenço M.V., Soares A.M. \& Fuly A.L. 2010. Antiophidian properties of plant extracts against Lachesis muta venom. J. Venom. Anim. Toxins incl. Trop. Dis. 16:311-323
Deng Y., Shi D., Yin Z., Guo J., Jia R., Xu J., Song X., Lv C., Fan Q., Liang X., Shi F., Ye G. \& Zhang W. 2012. Acaricidal activity of petroleum ether extract of neem (Azadirachta indica) oil and its four fractions separated by column chromatography against Sarcoptes scabiei var. cuniculi larvae in vitro. Exp. Parasitol. 130:475-477.

Du Y.H., Jia R.Y., Yin Z.Q., Pu Z.H., Chen J., Yang F., Zhang Y.G. \& Lu Y. 2008. Acaricidal activity of extracts of neem (Azadirachta indica) oil against the larvae of the rabbit mite Sarcoptes scabiei var. cuniculi in vitro. Vet. Parasitol. 157:144-148.

Embrapa 2006. Conceitos e aplicações dos adjuvantes. Embrapa Trigo, Passo Fundo, RS. Online. Disponível em <http://www.cnpt.embrapa.br/ biblio/do/p_56pdf> Acesso em 26 jan. 2017.

Evans G.O. 1992. Principles of Acarology. CAB International, Wallingford.

Gomes N.M., Rezende C.M., Fontes S.P., Matheus M.E., Pinto A.C. \& Fernandes P.D. 2010. Characterization of the antinociceptive and anti-inflammatory activities of fractions obtained from Copaifera multijuga Hayne. J. Ethnopharmacol. 128:177-183.

Hansen D., Haraguchi M. \& Alonso A. 2010. Pharmaceutical properties of 'sucupira' (Pterodon spp.). Braz. J. Pharm. Sci. 46:607-616.

Izumi E., Ueda-Nakamura T., Veiga Jr V.F., Pinto A.C. \& Nakamura C.V. 2012. Terpenes from Copaifera demonstrated in vitro antiparasitic and synergic activity. J. Med. Chem. 55:2994-3001.

Jesus N.Z.T., Lima J.C.S., Silva R.M., Espinosa M.M. \& Martins D.T.O. 2009. Levantamento etnobotânico de plantas popularmente utilizadas como antiúlceras e antiinflamatórias pela comunidade de Pirizal, Nossa Senhora do Livramento/MT, Brasil. Revta Bras. Farmacogn. 19:130-139.

Mazzonetto F. \& Vendramim J. 2003. Effect of powders from vegetal species on Acanthscelides obtectus (Say) (Coleóptera: Bruchidae) in stored bean. Neotrop. Entomol. 32:145-149.

Moraes W.F., Galdino P.M., Nascimento M.V.M., Vanderlinde F.A., Bara M.T.F., Costa E.A. \& Paula J.R. 2012. Triterpenes involved in the anti-inflammatory effect of ethanolic extract of Pterodon emarginatus Vogel, 1837 stem bark. J. Nat. Med. 66:202-207.

Nong X., Fang C.L., Wang J.H., Gu X.H., Yang D.Y., Liu T.F., Fu Y., Zhang R.H., Zheng W.P., Peng X.R., Wang S.X. \& Yan G.Y. 2012. Acaricidal activity of extract from Eupatorium adenophorum against the Psoroptes cuniculi and Sarcoptes scabiei in vitro. Vet. Parasitol. 187:345-349.

Oliveira L.G.S., Ribeiro D.A., Saraiva M.E., De Macêdo D.G., Macedo J.G.F., Pinheiro P.G. \& De Menezes I.R.A. 2017. Chemical variability of essential oils of Copaifera langsdorffii Desf. in different phenological phases on a savannah in the Northeast, Ceará, Brazil. Industrial Crops and Products 97:455-464.

Pence D.B. \& Ueckermann E. 2002. Sarcoptic mange in wildlife. Rev. Sci Tech. 21:385-398.

Pereira E.M.R., Gomes T., Freire N.R., Aguiar E.V., Brandão M.G.L. \& Santos V.R. 2011. In vitro Antimicrobial Activity of Brazilian Medicinal Plant Extracts against Pathogenic Microorganisms of Interest to Dentistry. Planta Med. 77:401-404.

Poppenga R.H. 2007. Veterinary Herbal Medicine. Mosby, St Louis.

Porfírio Z., Melo-Filho G.C., Alvino V., Lima M.R.F. \& Sant'ana A.E.G. 2009. Atividade antimicrobiana de extratos hidroalcoólicos de Lafoensia pacari A. St Hil., Lythraceae, frente a bactérias multirresistentes de origem hospitalar. Revta Bras. Farmcogn. 19:785-789.

Ravindran R., Juliet S., Sunil A.R., Kumar K.G.A., Nair S.N., Amithamol K.K., Bandyopadhyay A., Rawat A.K.S. \& Ghosh S. 2012. Acaricidal activity of Cassia alata against Rhipicephalus (Boophilus) annulatus. Exp. Appl. Acarol. 56:69-74.

Reichling J., Schnitzler P., Suschke U. \& Saller R. 2009. Essential oils of aromatic plants with antibacterial, antifungal, antiviral, and cytotoxic properties: an overview. Forsch. Komplementmed., Frankfurt, 16:79-90.

Ribeiro T.G., Nascimento A.M., Henriques B.O., Chávez-Fumagalli M.A., Franca J.R., Duarte M.C. \& Costa L.E. 2015. Antileishmanial activity of standardized fractions of Stryphnodendron obovatum (barbatimão) extract and constituent compounds. J. Ethnopharmacol. 165:238-242.

Rogério A.P., Sá-Nunes A., Albuquerque D.A., Soares E.G. \& Faccioli L.H. 2008. Anti-eosinophilic effect of Lafoensia pacari A St Hil. in toxocariasis. Phytomedicine 15:348-357. 
Santos A.P., Zatta D.T., Moraes W.F., Bara M.T.F., Ferri P.H., Silva M.R. \& Paula J.R. 2010. Composição química, atividade antimicrobiana do óleo essencial e ocorrência de esteróides nas folhas de Pterodon emaginatus. Vogel, 1837 Fabaceae. Revta Bras. Farmacogn. 20:891-896.

Sigma Aldrich. 2017. Missouri, Tween $20^{\circledR}$ Product Information. Disponível em <http://www.sigmaaldrich.com/content/dam/sigma-aldrich/docs/Sigma/Product_Information_Sheet/1/p9416pis.pdf> Acesso em 20 fev 2017.

Silva Júnior I.F., Raimondi M., Zacchino S., Cechinel Filho V., Noldin V.F., Rao V.S., Lima J.C.S. \& Martins D.T.O. 2010. Evaluation of the antifungal activity and mode of action of Lafoensia pacari A. St Hil., Lythraceae, stem-bark extracts, fractions and ellagic acid. Revta Bras. Farmacogn. 20:422-428.

Sobestiansky J., Linhares G.F.C., Moreno A.M. \& Matos M.P.C. 2012. Ectoparasitoses, p.335-351. In: Sobestiansky Y. \& Barcellos D. (Eds), Doenças dos Suínos. Canône Editorial, Goiânia.

Souza T.M., Severi J.A., Silva V.Y.A., Santos E. \& Pietro R.C.L.R. 2007. Bioprospecção de atividade antioxidante e antimicrobiana da casca de Stryphnodendron adstringens (Mart.) Coville (Leguminosae-Mimosoidae). Revta Ciênc. Farm. Básica Apl. 28:221-226.

Souza G.A., Da Silva N.C., De Souza J., De Oliveira K.R., Da Fonseca A.L., Baratto L.C. \& Moraes W.P. 2017. In vitro and in vivo antimalarial potential of oleoresin obtained from Copaifera reticulata Ducke (Fabaceae) in the Brazilian Amazon rainforest. Phytomedicine 24:111-118.
Veiga Junior V.F. \& Pinto A.C. 2002. 0 gênero Copaifera L. Química Nova, São Paulo, 25(2)273-286.

Walton S.F., McKinnon M., Pizzutto S., Dougall A., Willians E. \& Currie B.J. 2004. Acaricidal activity of Melaleuca alternifolia (Tea Tree) oil: in vitro sensitivity of Sarcoptes scabiei var. hominis to terpinen-4-ol. Arch. Dermatol. 140:563-566.

Walton S.F., Myerscough M.R. \& Currie B.J. 2000. Studies in vitro on the relative efficacy of current acaricides for Sarcoptes scabiei var. hominis. Trans. R. Soc. Trop. Med. Hyg. 94:92-96.

Walton S.F., Pizzutto S., Slender A., Viberg L.J., Holt D., Hales B.J., Kemp D.J., Currie B., Rolland J.M. \& O’hehir R. 2010. Increased allergic immune response to Sarcoptes scabiei antigens in crusted versus ordinary scabies. Clin. Vaccine Immunol. 17:1428-1438.

Webber G.L. 2009. Efeitos de extratos de barbatimão Stryphnodendron coriaceum na biologia de Spodoptera frugiperda. Dissertação de Mestrado em Agronomia, Centro de Ciências Agrárias, Universidade Federal do Piauí, Teresina. 95p.

Xu J., Fan Q.J., Yin Z.Q., Li X.T., Du Y.H., Jia R.J., Wang K.Y., Ly C., Ye G., Geng Y., Su G., Zhao L., Hu T.X., Shi F., Zhang L., Wu C.L., Tao C., Zhang Y.X. \& Shi D.X. 2010. The preparation of neem oil microemulsion (Azadirachta indica) and the comparison of acaricidal time between neem oil microemulsion and other formulations in vitro. Vet. Parasitol. 169:399-403. 